\title{
Evaluation of Quality of Life and Tendency to Negative Cognitive Errors in Children with Primary Nocturnal Enuresis
}

\author{
Behçet Şimşek, (i) Julide Özgür
}

Department of Children, University of Health Sciences Turkey, Haydarpaşa Numune Health Application and Research Center, Istanbul, Turkey

\begin{abstract}
Introduction: Enuresis nocturna is an important health problem having adverse effects on the child's emotional state, social development and self-esteem and might be associated with various psychiatric conditions. Children with chronic diseases such as obesity and cancer have been reported to have decreased life quality. It has been reported that adverse life events in children lead to development of negative cognitive structure and mental problems in adulthood. It was aimed to evaluate the social and psychological well-being of 8-17 age group cases diagnosed with primary enuresis nocturna through "Pediatric Quality of Life Questionnaire (PedsQL)" and the probable negative cognitive structures for the same group through "Children's Negative Cognitive Error Questionnaire (CNCEQ)."

Methods:"Pediatric Quality of Life Questionnaire (PedsQL)" and "Children's Negative Cognitive Error Questionnaire (CNCEQ)" were applied to all children included in the study with written consent from their families. The NCSS (Number Cruncher Statistical System) 2007(Kaysville, Utah, USA) program was used for statistical analysis.

Results: In the study, 39.3\% ( $n=59)$ girls and 60.7\% ( $n=91$ ) boys, 150 children between the ages of 8 and 17 with a mean age of $10.40 \pm 2.07$ years were included. The total score of children in the enuretic study group had significantly lower PedsQL total score than healthy children $(p=0.001 ; p<0.01)$. Total CNCEQ total scores of enuretic children were significantly higher than the control group $(p=0.001 ; p<0.01)$.

Discussion and Conclusion: To our knowledge, we are the first to determine that children with primary nocturnal enuresis develop negative cognitive errors. Besides, it was observed that their quality of life was significantly lower compared to their healthy peers.

Keywords: Cognitive errors; children; enuresis nocturnal; quality of life.
\end{abstract}

$E^{n}$ nuresis nocturna is defined as involuntary nocturnal wetting during sleep in children over 5 years of age without congenital or acquired central nervous system damage ${ }^{[1]}$. It is one of the most common urological problems seen in childhood ${ }^{[2]}$. Absence of urinary control from birth is defined as primary enuresis, and the resumption of urinary incontinence after a dry period longer than 6 months is defined as secondary enuresis ${ }^{[1,2]}$. Biological and psychosocial factors are associated with the etiology of enuresis; It has been shown that it is more common in children living in social institutions, with low education and socioeconomic status, and in crowded families ${ }^{[3]}$.

Correspondence (İletişim): Behçet Şimşek, M.D. Saglik Bilimleri Universitesi Hamidiye Tip Fakultesi, Haydarpasa Numune Saglik Uygulama ve Arastirma Merkezi, Cocuk Klinigi, Istanbul, Turkey

Phone (Telefon): +905305881130 E-mail (E-posta): behcetmd@gmail.com

Submitted Date (Başvuru Tarihi): 23.05.2020 Accepted Date (Kabul Tarihi): 09.06.2020

Copyright 2020 Haydarpaşa Numune Medical Journal

OPEN ACCESS This is an open access article under the CC BY-NC license (http://creativecommons.org/licenses/by-nc/4.0/) 
The prevalence of enuresis nocturna varies according to societies. While $33 \%$ of five-year-old American children and $7 \%$ of 11 -year-olds wet their bed; the rate of bed wetting in 5-year-old European children has been reported to be $9-19 \%[4,5]$. In a study conducted in Istanbul in the age group of 6-12, the prevalence in children from low and high socioeconomic regions was found to be $25.5 \%$ and $16 \%$, respectively ${ }^{[5]}$.

Although it has not been proven that enuresis is inherently a psychiatric condition; it has been reported that it may result in avoidance of social activities and parental pressure and may be associated with various psychiatric conditions such as sleep disorders, chronical lack of self-esteem and attention disorder ${ }^{[2,6-8]}$.

Following the World Health Organization's definition of health as a state of complete physical, mental and social well-being, the concept "quality of life" has emerged, which cares for what a person feels and takes the individual into consideration as a whole ${ }^{[9]}$. "Health-related general quality of life" (HRQOL) is expressed as the patient's perception of the effects of a disease and its treatment and indicates the physical, social and mental well-being of the person. "Health-related general quality of life scale" reflects the psychosocial consequences of physical health problems. It is important to know the HRQOL of the person in order to evaluate the treatment before and after and to determine health policies. In this context; scales measuring HRQOL have been developed ${ }^{[9-12]}$.

Cognitive structure may affect the susceptibility to mental disorders as well as personality traits. Studies show that the most important changes occur before the age of 12 , and the cognitive structure becomes stable with age. Childhood is critical in terms of investigating the factors that lead to the development of negative cognitive structure ${ }^{[13,14]}$. It has been reported that negative life events in childhood lead to the development of a negative cognitive structure and are associated with mental problems in adulthood ${ }^{[13,15]}$. Today, there is a need for reliable scales that can identify high-risk groups at an early stage and prevent childhoodrelated adult problems. Children's Negative Cognitive Error Questionnaire (CNCEQ) was developed by Leitenberg to identify cognitive distortions in children. Karakaya et al. conducted a validity-reliability study of the scale in Turkish $^{[13,16]}$.

Considering the negative effects of enuresis on children's emotional state, self-esteem and social development; it can be predicted that enuretic children may be at risk in terms of their potential to develop negative thoughts that may affect their HRQOL and adult health ${ }^{[17,18]}$. This study aims to assess the social and psychological well-being of the patients with primary enuresis nocturna who applied to our unit via the "Pediatric Quality of Life Questionnaire" and the probable negative cognitive structures for the same group via "Children's Negative Cognitive Error Questionnaire (CNCEQ)."

\section{Materials and Methods}

A total of 150 children were included in the study consisting of 100 children aged 8-17 with primary enuresis nocturna as a study group, who were followed up in the Pediatric Nephrology Unit- a tertiary care unit- and of 50 healthy children with no chronic diseases and having the similar age and sex with the study group as the control group. Cases with secondary enuresis such as meningomyelocele and neurogenic bladder were excluded from the study. The parents of the candidate children were informed about the study, and the cases with were involved in the study with their written consent. Approval was obtained from the ethics committee of our hospital where the study was conducted.

In the evaluation of the level of HRQOL in the cases involved in the study, the "Pediatric Quality of Life Questionnaire (PedsQL)" the validity and reliability for Turkish of which was confirmed by Memik et al. ${ }^{[10-12]}$. Although the discussion continues on whether children's quality of life assessments should be made by the parents or by the children themselves, in this study the evaluations were made by the case itself since this way was found to be more valuable in recent years ${ }^{[19]}$. The questionnaire in the evaluation form consists of 23 questions about the children's health status and activities, emotional state, difficulties faced with their peers and on their school life. The scale was scored in 3 areas. Firstly; "total scale score" (TSS), secondly; the "physical health total score" (PHTS), and thirdly, the "psychosocial health total score" (PSHTS) was calculated, which was obtained through the calculation of item scores evaluating emotional, social and school functionality. The items are scored between 0 and 100 . The answers were scored as follows: If it is marked as "never", $0=100$; as "rarely" $1=75$, as "sometimes" was $2=50$, as "often" $3=25$, as "almost always" $4=0$. Adding up the scores and dividing it by the number of marked items, the total score was obtained. If more than $50 \%$ of the scale is not filled, the scale is excluded from evaluation. The higher "Total Score for Pediatric Quality of Life Questionnaire", the better health-related quality of life should be perceived ${ }^{[11]}$. 
The PedsQL, the validity-reliability study of which conducted by Karakaya et al. was used to evaluate possible cognitive distortions in children ${ }^{[13,16]}$. The scale was filled in by the participant itself. It is a five-point Likert type scale where each item is scored between 1-5. "Almost exactly like my opinion" was evaluated with 5 points, "I never think like that" was evaluated with 1 point. The total scale score ranges between 24-120. The higher the score is, the higher the "cognitive distortions" should be understood $^{[13]}$.

\section{Statistical Analysis}

The NCSS (Number Cruncher Statistical System) 2007 (Kaysville, Utah, USA) program was used for statistical analysis. In addition to descriptive statistical methods, Student's t-test was used for comparing two groups of quantitative data with normal distribution whereas Mann Whitney $U$ test for comparison of quantitative data and Pearson ChiSquare test for comparison of qualitative data were used. Inter-variable relationships were examined by Pearson correlation analysis and the significance was evaluated at least $p<0.05$ level.

\section{Results}

In the study, 150 children consisting of $39.3 \%(n=59)$ girls and $60.7 \%$ male $(n=91)$ between the ages of 8 and 17 and the mean ages are $10.40 \pm 2.07$ years were included.

The distribution of bed-wetting at night is given in Table 1. The weekly number of bed-wetting varies between 1-7 and the mean was $2.99 \pm 1.60$ whereas the median was 3 times.

When the cases are seperated into the study group and the control group, demographic characteristics by groups are

Table 1. Distributions Regarding Bed-Wetting Situation

\begin{tabular}{lc}
\hline & $\mathbf{n}(\%)$ \\
\hline $\begin{array}{l}\text { Bed-Wetting } \\
\text { No }\end{array}$ & $50(33.3)$ \\
Yes & $100(66.7)$ \\
Number of bed-wetting (weekly) $(\mathrm{n}=100)$ & \\
$\quad$ Min-Max (Median) & $1-7(3)$ \\
Avg \pm Ss & $2.99 \pm 1.60$ \\
1 times & $10(10.0)$ \\
2 times & $39(39.0)$ \\
3 times & $25(25.0)$ \\
$\geq 4$ times & $26(26.0)$ \\
Treatment (n=100) & \\
No & $59(59.0)$ \\
Yes & $41(41.0)$ \\
\hline
\end{tabular}

given in Table 2. No significant difference was found between the two groups by age, gender and socio-cultural status of their parents $(p>0.05)$; however, the rate of family history for enuresis in children with enuresis nocturnal was found to be significantly higher than the control group $(p=0.001 ; p<0.01)$. When the sleep intensity of the children was evaluated among the groups, the rate of heavy sleep in the enuretic study group was found to be significantly higher than the non-enuretic control group $(p=0.001$; $\mathrm{p}<0.01$ ).

The Pediatric Quality of Life Questionnaire (PedsQL) total score is between 28.3 and 100 points; the average is $81.01 \pm 14.44$ points, Cronbach's alpha value is 0.947 ; the scale was found to be quite reliable. The evaluation of PedSQL according to the study and control groups is given in Table 3. Children in the enuretic study group had significantly lower PedsQL total score than healthy children $(p=0.001 ; p<0.01)$. Both physical and psychosocial health scores of enuretic children were also lower than nonenuretic children $(p<0.01)$.

The rates of physical and psychosocial areas affecting the quality of life of the children involved in the study are given in Table 4. It was revealed that $89.0 \%$ of enuretic children were affected by affective issues, $87 \%$ by school, and $83 \%$ by social relations with their peers (Table 4).

For all children involved in the study, the total CNCEQ

Table 2. Evaluation of Demographic Characteristics by Groups

\begin{tabular}{|c|c|c|c|}
\hline & $\begin{array}{l}\text { Study Group } \\
\qquad \begin{array}{c}(n=100) \\
n(\%)\end{array}\end{array}$ & $\begin{array}{l}\text { Control Group } \\
\qquad \begin{array}{c}(n=50) \\
n(\%)\end{array}\end{array}$ & $\mathbf{p}$ \\
\hline \multicolumn{4}{|l|}{ Age (Year) } \\
\hline Min-Max (Median) & $7-17(10)$ & $8-16(10)$ & ${ }^{\mathrm{a}} 0.279$ \\
\hline Avg \pm Ss & $10.27 \pm 2.03$ & $10.66 \pm 2.14$ & \\
\hline \multicolumn{4}{|l|}{ Cinsiyet } \\
\hline \multicolumn{4}{|l|}{ Sex } \\
\hline Girl & $39(39.0)$ & $20(40.0)$ & $\mathrm{b}_{0.906}$ \\
\hline Boy & $61(61.0)$ & $30(60.0)$ & \\
\hline \multicolumn{4}{|l|}{ Socio-Cultural Status } \\
\hline Lower Middle Class & $35(35.0)$ & $10(20.0)$ & $\mathrm{b}_{0.059}$ \\
\hline Middle Class and Uppe & er $65(65.0)$ & $40(80.0)$ & \\
\hline \multicolumn{4}{|l|}{ Family History } \\
\hline No & $35(35.0)$ & $39(78.0)$ & ${ }^{b} 0.001^{* *}$ \\
\hline Yes & $65(65.0)$ & $11(22.0)$ & \\
\hline \multicolumn{4}{|l|}{ Sleep Intensity } \\
\hline Low & $33(33.0)$ & $44(88.0)$ & ${ }^{b} 0.001^{* *}$ \\
\hline High & $67(67.0)$ & $6(12.0)$ & \\
\hline
\end{tabular}

aStudent t Test; bearson Chi-square Test; ${ }^{* *} \mathrm{p}<0.01$. 
Table 3. Evaluation of the Pediatric Quality of Life Scale (PedsQL) by Groups

\begin{tabular}{lcc}
\hline & $\begin{array}{c}\text { Study group } \\
(\mathbf{n = 1 0 0 )} \\
\mathbf{A v g} \pm \text { Ss }\end{array}$ & $\begin{array}{c}\text { Control group } \\
(\mathbf{n}=\mathbf{5 0}) \\
\text { Ort } \pm \text { Ss }\end{array}$ \\
\hline Total Score (TSS) & $76.18 \pm 14.76$ & $90.67 \pm 7.12$ \\
Physical Health Total Score (PHTS) & $80.50 \pm 16.73$ & $90.37 \pm 9.44$ \\
Psychosocial Health Total Score (PSHTS) & $73.88 \pm 15.85$ & $90.83 \pm 6.80$ \\
\hline
\end{tabular}

Student t Test; ${ }^{* *} \mathrm{p}<0.01$.

score was between 24 and 118 points; the mean is $42.46 \pm 17.72$ points. Examining the internal consistency of the questions that make up the scale, Cronbach's alpha value is 0.971 and the scale was found to be very reliable. The evaluation of CNCEQ according to the groups is given in Table 5. Total CNCEQ total scores of enuretic children were significantly higher than the control group $(p=0.001$; $p<0.01$ ) (Fig. 1). No significant difference was found between the CNCEQ total scores by their sex in the study group ( $p>0.05)$.

Table 4. Evaluation of the Pediatric Quality of Life Scale (PedsQL) Questions by the Groups

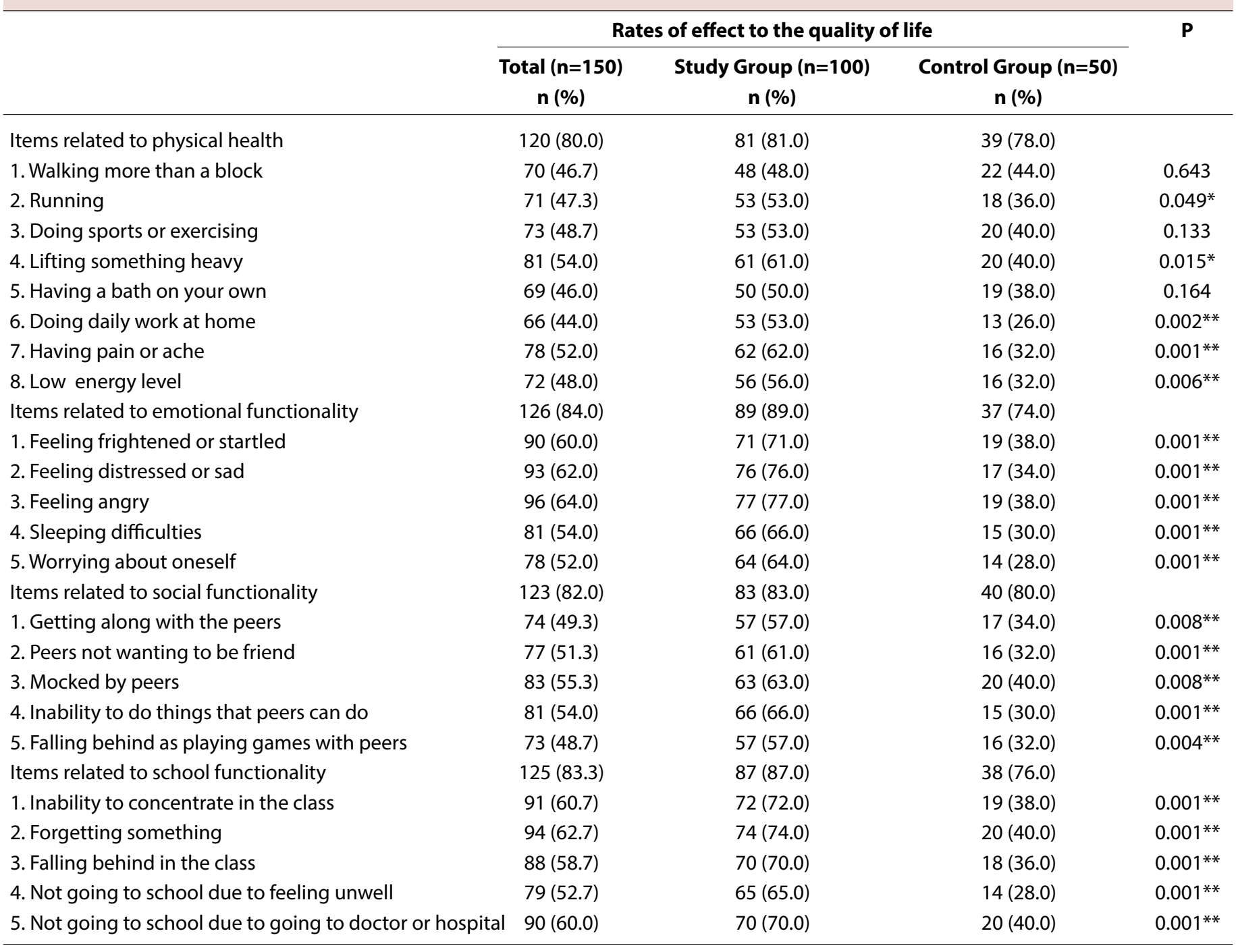


Table 5. Evaluation of the Children's Negative Cognitive Error Questionnaire (CNCEQ) by Groups

\begin{tabular}{lccc}
\hline CNCEQ & $\begin{array}{c}\text { Study Group } \\
(\mathbf{n}=\mathbf{1 0 0 )} \\
\text { Avg } \pm \text { Ss }\end{array}$ & $\begin{array}{c}\text { Control Group } \\
(\mathbf{n = 5 0 )}\end{array}$ & $\mathbf{p}$ \\
& Avg \pm Ss & \\
\hline Total score $($ CNCEQ) & $48.15 \pm 18.97$ & $31.08 \pm 5.42$ & $0.001^{* *}$ \\
\hline Student t Test; ${ }^{* *} \mathrm{p}<0$. & & & \\
\hline
\end{tabular}

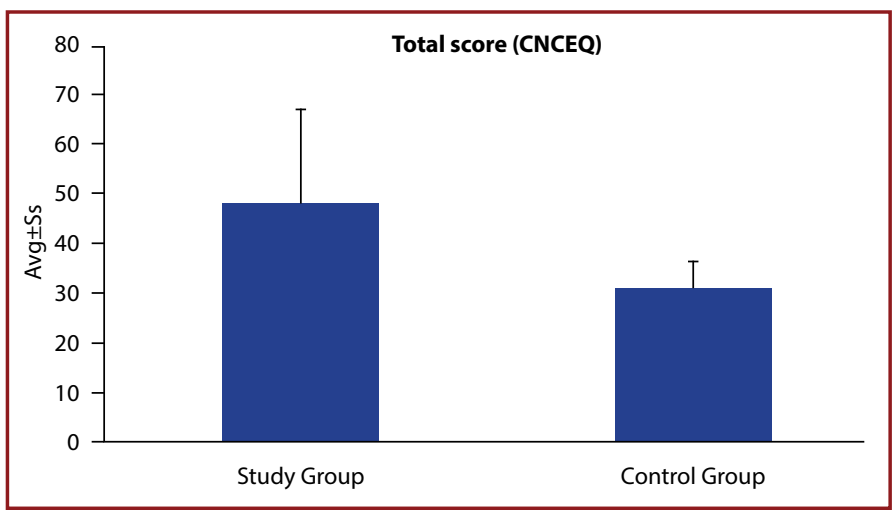

Figure 1. Distribution of the total scores of the Children's Negative Cognitive Error Questionnaire (CNCEQ).

\section{Discussion}

Enuresis nocturna is annoying in many ways for both the child and the family. This situation leads to problems such as fear, decrease in self-esteem, and asocial personality disorder in children; may affect negatively the daily activities of the child ${ }^{[20]}$. Wagner and Geffken reported that $65 \%$ of the children with bed-wetting at night are not happy with this situation; whereas in our study $76 \%$ of the cases stated that they felt distressing or sad. This relative high rate for the children involved in our study can be associated with sociocultural or environmental differences $^{[21]}$.

The fact that $61 \%$ of the enuresis nocturnal children involved in our study were boys, 39\% were girls; showing that the rate of bed-wetting was higher in boys. Our results are consistent with the data of Özçetin and Erguvan et al. $(64.1 \% \text { for boys and } 60 \% \text { for girls respectively })^{[22,23]}$.

Although there are publications associating the sociocultural status of parents and enuresis nocturna in their children; no significant relationship was found between the sociocultural status of the family and the rate of bed-wetting children in our study. This fact can be explained by the homogeneous composition of the population provided service in our hospital which is consisted of families from middle and upper levels of sociocultural strata ${ }^{[24,25]}$.
It is considered that there is no neurophysiological sleep disorder in enuretic children and that the problem is due to the high threshold of awakening. Children bed-wetting at night are reported to be hard-to-awakened and heavy sleeper. Assessing the sleep conditions, $67 \%$ of the enuretic children involved in our study and $12 \%$ of the children in the control group were found to having heavy sleep. In parallel with the related literature, it has been confirmed that the rate of bed-wetting are significantly correlated with sleep intensity $(p=0.001 ; p<0.01)^{[23]}$.

In addition to publications reporting that the rate of family histories for children with primary enuresis nocturnal are $90 \%$; in our study, $65 \%$ of the cases has been found having a related family history. We found that the rate of wetting was higher in those with a family history $(p=0.001 ; p<0.01)$ [23]. We supported the view that children with a family history have a high risk for enuresis ${ }^{[21-25]}$.

"Pediatric Quality of Life Questionnaire" has been applied to children diagnosed with obesity, cancer and chronic diseases including different age groups in various countries in the literature. It has been revealed that the quality of life decreases at different rates in both the total score averages and the psychosocial health scores or physical health scores ${ }^{[26-28]}$. Differences in mean scores in studies conducted with quality of life may be related to disease groups, demographic characteristics, and variation in lifestyle related to the disease ${ }^{[26-28]}$. The quality of life of enuretic children included in our study was found to be significantly lower than the control group $(76.18 \pm 14.76$ versus $90.67 \pm 7.12$ points). Psychosocial health total score was statistically affected the most $(p=0.001 ; p<0.01)$ (Table 3$)$. When the rates of PedsQL affected by enuretic children are examined; it was observed that the negative effects were mostly in items related to emotional functionality, and the least affected were in items related to physical health (Table 4). The enuretic children who participated in our study stated that they felt sad or sad, angry, scared, they forgot some things about school, could not concentrate in class, lagged behind in their classes, they could not do things that their peers could do and were mocked by their peers, felt or ache.

Although the opinion that enuresis is basically a psychiatric condition has not been proven; it is not a trivial situation; it has been reported that if not treated, it may result in situations such as lack of self-confidence, avoidance of social activities, and parental pressure. This may negatively affect prognosis and response to treatment. Enuresis nocturna is an important health problem that needs to be taken into 
account, as it may lead to sleep disorders, chronic self-esteem, and may be associated with various psychiatric conditions such as attention deficit disorder ${ }^{[2,6-8]}$. The fact that enuretic children who participated in our study frequently express feelings of sadness, anger and fear from the criteria of PedsQL may be responsible for attention deficit symptoms such as sleep disorders, inability to concentrate at school, and forgetfulness. Feelings such as inability to achieve the success of their peers, anxiety of being ridiculed, lagging behind in their classes and feeling pain can be associated with the permanent lack of self-confidence that may develop. We think that the study data support the literature information.

Scale for assessing negative cognitions in children and adolescents are limited in Turkey. As stated before, in this study the "negative thoughts evaluation scale in children", developed by Leitenberg and confirmed by Karakaya and adapted to our language, was used to evaluate negative thoughts and automatic negative thoughts in enuretic children ${ }^{[13,16]}$. To our knowledge, this scale has been applied for the first time in enuretic children in this study. Although Karakaya reported that there were more cognitive errors in girls; no significant difference was found among children according to their sex in our study ( $>0.05$ ). In addition, negative thoughts expressed by the total CNCEQ total score in the enuretic group were found to be significantly higher than the healthy control group $(p=0.001 ; p<0.01)$ (Table 9).

Many studies show that mental problems in adulthood originate from childhood and adolescence and emphasize the importance of preventing, identifying and treating mental problems in childhood ${ }^{[4,14,15,17]}$. We observed that, as shown for the first time to our knowledge in this study; children with primary enuresis nocturnal develop negative thoughts and that these children had a significantly lower quality of life compared to their healthy peers.

\section{Conclusion}

In conclusion, this study emphasizes that enuresis nocturna is not a negligible condition simply limited to the wetting of the bed. Night wetting can trigger negative thoughts in children, reduce the quality of life, and have negative effects on child mental health. More importantly, we think that enuresis nocturna is a condition that has widespread effects that can disrupt individual and social health, especially the mental well-being of the cases in adulthood, and should be dealt with seriously after childhood.
Ethics Committee Approval: The Ethics Committee of Haydarpaşa Numune Training and Research Hospital provided the ethics committee approval for this study (E.8147/19.03.2018).

Peer-review: Externally peer-reviewed.

Authorship Contributions: Concept: B.S.; Design: B.S.; Data Collection or Processing: B.S., J.O.; Analysis or Interpretation: B.S., J.O.; Literature Search: B.S., J.O.; Writing: B.S.

Conflict of Interest: None declared.

Financial Disclosure: The authors declared that this study received no financial support.

\section{References}

1. Avanoğlu A, Baskın E, Söylemezoğle O, Tekgül S, Ziylan O, Zorludemir Ü. Türkiye Enürezis Çalışma Grubu; Türkiye Enürezis Kılavuzu. 2010.

2. Nevéus T, Fonseca E, Franco I, Kawauchi A, Kovacevic L, Nieuwhof-Leppink Aet al. Management and treatment of nocturnal enuresis-an updated standardization document from the International Children's Continence Society. J Pediatr Urol 2020;16:10-9. [CrossRef]

3. Gür E, Turhan P, Can G, Akkus S, Sever L, Güzelöz S, et al. Enuresis: prevalence, risk factors and urinary pathology among school children in Istanbul, Turkey. Pediatr Int 2004;46:58-63.

4. Byrd RS, Weitzman M, Lanphear NE, Auinger P. Bed-wetting in US children: epidemiology and related behavior problems. Pediatrics 1996;98:414-9.

5. Carman KB, Ceran O, Kaya C, Nuhoglu C, Karaman MI. Nocturnal enuresis in Turkey: prevalence and accompanying factors in different socioeconomic environments. Urol Int 2008;80:362-6. [CrossRef]

6. Hägglöf B, Andrén $O$, Bergström $E$, Marklund L, Wendelius M. Self-esteem before and after treatment in children with nocturnal enuresis and urinary incontinence. Scand J Urol Nephrol Suppl 1997;183:79-82.

7. Collis D, Kennedy-Behr A, Kearney L. The impact of bowel and bladder problems on children's quality of life and their parents: A scoping review. Child Care Health Dev 2019;45:1-14.

8. Van Herzeele C, Dhondt K, Roels SP, Raes A, Hoebeke P, Groen LA, et al. Desmopressin (melt) therapy in children with monosymptomatic nocturnal enuresis and nocturnal polyuria results in improved neuropsychological functioning and sleep. Pediatr Nephrol 2016;31:1477-84. [CrossRef]

9. Fidaner H, Elbi H, Fidaner C, Eser SY, Eser E, Göker E. Yaşam Kalitesinin ölçülmesi, WHOQOL-100 VE WHOQOL-BREF. (3P) Dergisi 1999;7:5-13.

10. Memik NÇ, Ağaoğlu B, Coşkun A, Karakaya I. Çocuklar için Yaşam Kalitesi Ölçeğinin 8-12 Yaş Çocuk Formunun Geçerlilik ve Güvenilirliği. Turk J Child Ment Health 2008;15:87-98.

11. Varni JW, Seid M, Kurtin PS. PedsQL 4.0: reliability and validity of the Pediatric Quality of Life Inventory version 4.0 generic core scales in healthy and patient populations. Med Care 2001;39:800-12. [CrossRef]

12. Memik NÇ, Ağaoğlu B, Coşkun A, Üneri Ö, Karakaya I. Çocuk- 
lar için Yaşam Kalitesi ölçeğinin 13-18 Yaş Ergen Formunun Geçerlik Ve Güvenilirliği. Turk Psikiyatri Derg 2007;18:353-63.

13. Karakaya I, Coşkun A, Ağaoğlu B, et al. Çocukluktaki Olumsuz Düşünceleri Değerlendirme Ölçeği Geçerlik-Güvenilirlik Çalışması. Tuurk Psikiyatri Derg 2007;18:1-8.

14. Garber J, Flynn C. Predictors of depressive cognitions in young adolescents. Cognit Ther Res 2001;4:353-75. [CrossRef]

15. Beck AT. Theoretical perspectives on clinical anxiety. In: Tuma $\mathrm{AH}$, Maser JD, editors. Anxiety and Anxiety Disorders Hillsdale, NJ: Erlbaum; 1985. p. 183-96. [CrossRef]

16. Leitenberg H. Children's Negative Cognitive Errors Questionnaire (CNCEQ). University of Vermont, Burlington. Available from Harold Leitenberg, PhD, Department of Psychology, University of Vermont, Burlington VT 05405. 2002; harold.leitenberg@uvm.edu.

17. Butler R. Annotation: Night wetting in children: Psychological aspects. J Child Psychol Psychiatr 1998;39:453-63. [CrossRef]

18. Butler RJ, Redfern EJ, Forsythe I. The maternal tolerance scale and nocturnal enuresis. Behav Res Ther 1993;3:433-6. [CrossRef]

19. Wallander JL, Schmitt M, Koot HM. Quality of life measurement in children and adolescents: issues, instruments, and applications. J Clin Psychol 2001;57:571-85. [CrossRef]

20. Butler RJ. Nocturnal enursis: The child's experience. Oxford Butterworth Heinemann 1994;186-91.
21. Wagner WG, Geffken G. Enuretic children: How they view their wetting behaviour: Child Study J 1986;16:13-8.

22. Özçetin M, Uluocak N, Yılmaz R, Atılgan D, Erdemir F, Karaarslan E. Okul öncesi çocuklarında idrar kaçırmanın değerlendirilmesi. Çocuk Dergisi 2010;10:75-8. [CrossRef]

23. Ergüven $M$, Çelik Y, Deveci $M$, Yıldız N. primer enürezis nokturnada etiyolojik risk faktörleri. Turk Pediatri Ars 2004;39:83-7.

24. Chang P, Chen WJ, Tsai WY, Chiu YN. An epidemiological study of nocturnal enuresis in Taiwanese children. BJU Int 2001;87:678-81. [CrossRef]

25. Iscan B, Ozkayın N. Evaluation of health-related quality of life and affecting factors in child with enuresis. J Pediatr Urol 2020;16:195.e1-195.e7. [CrossRef]

26. Williams J, Wake M, Hesketh K, Maher E, Waters E. Health-related quality of life of overweight and obese children. JAMA 2005;293:70-6. [CrossRef]

27. Taş F. Kemoterapi Alan Çocukların Yaşadıkları Semptomların Yaşam Kalitesine Etkisi ve Ebeveynlerin Uygulamaları. İzmir: Ege Üniversitesi Sağlık Bilimleri Enstitüsü; 2009.

28. Durualp E, Nur FN, Yılmaz V, Alaybeyoğlu K. Kronik hastalığı olan ve olmayan çocukların ve ebeveynlerinin görüşlerine göre yaşam kalitelerinin karşılaştırılması. Ankara Üniversitesi Tıp Fakültesi Mecmuası 2010;63:55-63. [CrossRef] 